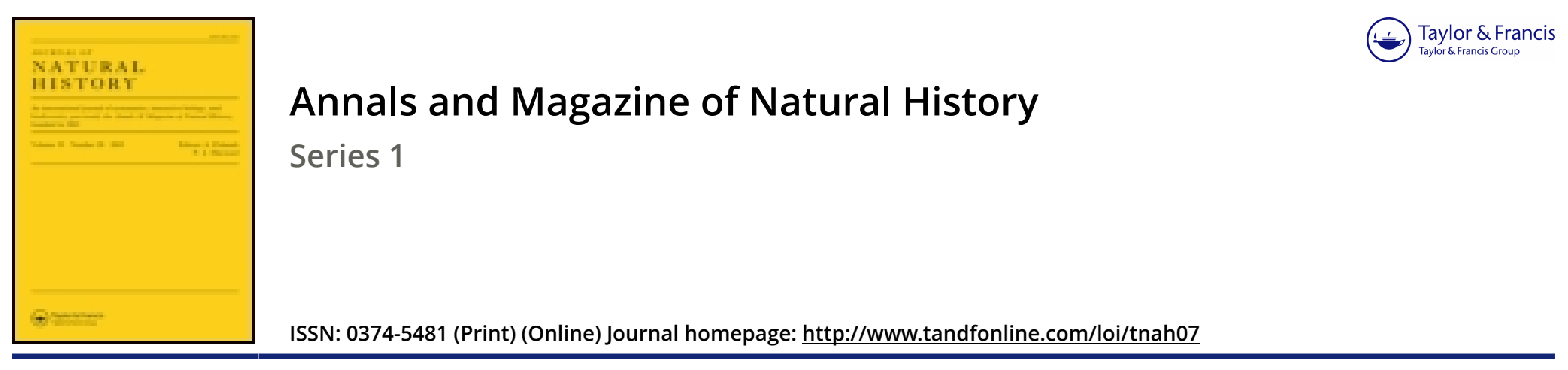

\title{
XIV.-Description of animal life in Nova Zembla
}

\section{K.E. von Baer}

To cite this article: K.E. von Baer (1839) XIV._-Description of animal life in Nova Zembla, Annals and Magazine of Natural History, 4:23, 145-154, DOI: $10.1080 / 00222933909512485$

To link to this article: http://dx.doi.org/10.1080/00222933909512485

\section{曲 Published online: 15 Mar 2010.}

Submit your article to this journal $\pi$

Џ Article views: 2

Q View related articles $\asymp$ 


\section{ANNALS OF NATURAL HISTORY.}

\section{XIV.-Description of Animal Life in Nova Zembla. By K. E. von BAER.*}

Now only the total want of trees, but also of every kind of shrub that would be large enough to attract the eye without being looked for, gives to the polar landscapes a peculiar and deeply impressive character.

In the first place all power of measurement is lost to the cye. From the want of the usual objects of known dimensions, trees and buildings, distances appear much less than they are, and for the same reason also the mountains are thought lower. This observation has often been made before and was not unknown to me, yet I found the deception, for which I was prepared, much more complete than I had expected. I knew indeed that on this very account an expedition which King Frederick the Second of Denmark fitted out for Greenland failed in its object.

Mogens Heinson, who at that time was considered an able seaman, commanded the ship: he came within sight of the coast of Greenland, and steered with a favourable wind towards it; but after sailing several hours in the same direction it appeared to him that he came no nigher to the shore. An apprehension seized him that some hidden force at the bottom of the sea held him fast; he turned the ship about and went back to Denmark, with the account that he had not been able to reach the coast of Greenland, having been enchained by a magnetic rock. With this experience and with the naïve declaration of Martens concerning Spitzbergen, "The distances seem quite near, but when they are to be walked over in the country it is quite another matter, and one soon becomes very weary," I was well acquainted, and yet I found the delusion much greater than I could have supposed, and to my

* 'Translated from Wiegmann's Archiv, part 2. 1839. Ann. Nat. Hist. Vol. 4. No. 23. Nov. 1839. 
eye so perfect that no consideration could rid me of it. I am also convinced that it does not depend upon the want of the accustomed objects alone, but likewise on a peculiar transparency of the air, for it is never so complete on cloudy as on bright days, and not so striking in level as in mountainous regions. In days or hours which are quite clear the air appears to be almost without colour, and as the heights in sight are partly covered with snow, and constituted in part of a dark stone, which appears darker by the contrast, so the small degree of colour which the air may possess cannot be perceived. The mountains therefore apparently advance quite near to the eye, and this perhaps in a greater degree to one who has been accustomed to see hills through a different aërial perspective.

Another effect of the want of trees and even of a vigorous growth of grass is the sensation of loneliness, which seizes not only on persons of reflection but even upon the roughest sailor. It is by no means a sensation of fear, but rather a solemn and elevating one, and can only be compared with the mighty impression which a visit to alpine regions always leaves behind.

The once-conceived idea that the morning of creation was dawning for the first time, and that life was yet to follow I found it impossible to repress. Nevertheless an animal is now and then seen to stir in Nova Zembla. Sometimes a great sea gull (Larus glaucus) is seen to hover in the air at some distance from the coast, or a swift lemming runs along the ground. These however are not sufficient to give life to the landscape. In calm weather a want of sounds and motion is felt, if, as in our case, an expedition be made into the interior, after the departure of the numerous geese which pass their moulting season on the sea shore. Besides, even the few land birds in Nova Zembla are mute, and the insect tribe, proportionally much scantier, is also noiseless. Even the polar fox is only heard at night. This total want of sounds, which especially prevails on serene days, reminds one of the stillness of the grave; and the lemmings, which coming forth from the earth, glide along in straight lines, and then again quickly vanish into it, appear like spectres. From the little motion one sees, in spite of these signs of animal life, it seems 
to be wanting. In other regions the leaves of tall plants and trees usually make even a gentle breeze perceptible to us, but a slight wind does not ruffle these lowly plants of the high north ; one might take them to be painted. A very few insects only are busy seeking to satisfy their little wants upon them. Of the numerous family of beetles only one individual has been found, a Chrysomela, which is perhaps a new species. On sunny days and in warm spots for instance, about the small projecting points of rock, a humble-bee is seen flying about, but it hardly hums, as is the case with us in moist weather. Flies and gnats are rather more numerous; but even these are so rare, so peaceful and languid, that in order to see them they must be sought for. I do not recollect having heard that any one of us had been bitten by a gnat, and one may truly long for the bite of a Lapland gnat, merely for the sake of perceiving life in nature. The most manifest proof of the rarity of insects in this country appears from the following circumstance, that we neither found the least trace of insect larva in a dead Walrus which had lain above fourteen days on the sea shore, nor in the bones of animals which had been killed in former years, even though they were not without dried flesh on some parts. The common saying in our funeral service, that man becomes a prey to worms, is not true with respect to the extreme north, and whoever dreads this lot has only to be buried in Nova Zembla or Spitzbergen, where even the universal decomposing forces of nature will act upon him but very slowly *.

The abundance or scarcity of insects is, next to the vegetable kingdom, the surest measure for the climate of a country. Both need for their subsistence a certain quantity and a certain duration of warmth. This never fails in the torrid zone, but as we approach the north it does so in an increasing degree. - Insects are however less easily transplanted than plants. That we know of no true insects from Spitzbergen may well be ascribed to this cause. M. Lehmann nevertheless observed ten species in Nova Zembla, and of these seven which are not parasitic. Fabricius described many more spe-

* At some depth the bodies remain frozen, but even above the earth they decay remarkably slowly. 
cies from Greenland, and amongst these even several butterflies, and Scoresby has added to them some few new species from East Greenland. But West Greenland, which in common life has been considered as the type of all northernmost countries, from its having already been known for a longer time through the Moravian missionaries, must, especially in its southern districts, be a more highly favoured country, for it has (even if we pay no attention to the old fabulous accounts) at the present time, under $61^{\circ} \mathrm{N}$. latitude, birch trees from 12 to 18 feet high, and of the thickness of a man's thigh, and among these mountain ash. (Egede, Account of the Greenland Mission, p. 78.) Egede found the corn, which he had sown as an experiment under the $64^{\circ}$ of latitude, not only in ear but already with small grains on the 13th of September (Ibid, p. 106 and 112). 'Things therefore wear a very different appearance from those in Nova Zembla, and the meteorological observations show sufficiently that it is much warmer there. But even regions which enjoy a much lower mean yearly temperature than Nova Zembla are much richer in animal life, if the summer do but develope more heat. To select a less known example I will refer to Nyshne-Kolymsk, with a mean temperature of $10^{\circ} \mathrm{C}$. According to Wrangell's observations the boundary of the lofty woods is not far off, and perhaps they would extend to this place were it not for the nearness of the coast, for at Nyshne-Kolymsk there are stunted Siberian cedars and bushes in plenty. During the short summer there the gnats arc an intolerable plague.

T'he coast of Nova Zembla is rendered far more lively than the interior of the country by the sea-birds which make their nests there. Their number and variety is indeed not so great as upon the Norwegian coast or some isles and cliffs of Iceland, but even here one finds the coast thickly filled with them in some spots, and they receive any one who approaches with loud cries. Above all, the Foolish Guillemot (Uria Troile), which is perhaps as numerous as all the other birds put together, drells in such colonies, sitting in thick troops and in many rows one above another upon the scarcely perceptible shelves of perpendicular rocks: they rouse themselves when anyone approaches, and cause the sides of the dark rock to appear spotted 
with their uplifted white bellies. The Russians call such a brooding place a bazaar. Thus this Persian word has been transplanted by Russian Walrus-fishers to the rocks of the frozen ocean and applied to birds in default of human inhabitants. Upon the points of isolated cliffs, and enduring no other birds ncar it, lives the large grey sea gull (Larus glaucus), which the Dutch whale-fishers, I know not why, whether from respect or a want of it, have named the Burgomaster. It seems to feel itself the lord of this creation, for before a whole company of fishermen it is bold enough to pick and choose from the fish that have been thrown upon the shore.

These birds are the best proofs that there is more to be had from the bottom of the sea than on land. In fact here the chief sum of animal life is sunk under the surface of the ocean. Small Crustacea are particularly numerous here, and above all the Gammari, which gather as thickly around a piece of flesh thrown into the water as do the gnats in Lapland about a warm-blooded animal. With a sieve one may take them up by thousands. When we threw lines in Matotschkin-Schar, the Walrus-fishers, who never took this trouble assured us that it would be quite in vain, for in the first place there were hardly any fish there, and moreover the Kapschaki (thus they call the Gammari) completely consume within a few hours sometimes the bait and sometimes the fish as soon as it is dead. In fact we seldom drew up anything but our empty lines.

Scanty as is the vegetation, it yet feeds a quantity of lemmings. Gentle declivities are frequently burrowed through in every direction by them. But the number of animals is not near so great as might be supposed from the quantity of burrows ; for by far the greater part are empty, which one may soon be convinced of by tracking them with dogs, but nevertheless their number is so considerable as to force us to ask how so many lemmings can find support upon such a vegetation. But it is also not impossible that the vegetation appears so small to the observer because the lemmings make a considerable portion of it invisible. If they devoured the roots not much of the vegetable kingdom of Nova Zembla could long remain, and the lemmings themselves would soon perish from want of nourishment. But those captured by us could in no 
way be brought to eat the smallest root. Since, therefore, when they are at large they certainly devour the flowers only and green parts, and since the plants of this country are all perennial, in the following year they again put forth a stem. I was still more surprised that when suffering the greatest hunger they would touch no Cryptogamia. It is a pity that the small number of ferns which have been found did not allow us to make trial whether these practical vegetable physiologists direct themselves according to the presence of spiral vessels or follow the divisions of the Linnaean system. There are two kinds of them; one seems to be Mus gronlandicus, Traill, or Mus hudsonius, Auct. They quite agree with the description which Richardson gives in the 'Fauna BorealiAmericana;' less with that of Pallas. The other species likewise appcars to me distinct from the Scandinavian lemming; in the colour the difference is truly striking. Pallas, who however seems only to have seen young animals, has enumerated it as a Russian variety of the Scandinavian lemming. The first is particularly distinguished by its tameness, for, fourand-twenty hours after it had been caught, it hardly made any attempt to escape when held free upon the hand, and one never sees two individuals of this species quarrelling together. The second, yellowish-brown species is much more ready to fight.

Next to the lemmings the polar foxes are also tolerably numerous. They find in the lemmings, in young birds, and in the sea-animals which are thrown up on the shore, a plentiful sustenance.

On the contrary, polar bears are seldom seen in summer; either because they avoid the places where they scent men, or because they only collect together on those parts of the coast where there is ice. The rein-deer also appear to have become rare, on the western coast at least, from the numerous winterings of late years of the seal-fishers. Not only were very few killed during our residence, but one of the companies which had passed the winter before in Nova Zembla, and had been advised to procure a provision of flesh by hunting the rein-deer, had not been able to obtain any. Wolves and common foxes, which, at least in the southern part of Nova Zembla, also sometimes occur, appear never to have been nume- 
rous even there. With this enumeration the list of land Mammalia would be complete, if MM. Pachtussow and Ziwolka had not, during their winter stay, seen a little white animal within their hut, which they in their journal call a mouse. As the animal seen, according to M. Ziwolka's testimony, must have been larger than a common domestic mouse, and therefore could not be an individual of the white variety of this animal brought by chance in some ship, I am doubtful as to what it can be. On one hand it is stated that the North American lemmings become white in winter, but yet not so completely white as the animals of the weazel genus; on the other hand it might also be possible that the little animal noticed was a weazel. In Spitzbergen also a little white mammal has been observed, whose systematic determination is uncertain.

The sea Mammalia are of more importance, and expensive expeditions are yearly fitted out for the purpose of catching them by the inhabitants of the coast of the White Sea ; but unhappily the booty is so uncertain that they may be compared to a game at hazard. If the sea is unusually free from ice the losses are very great. One day however may repay the loss of a whole year. For this reason these undertakings have always been renewed for centuries, even though they sometimes entirely fail. The result of a fortunate year is usually this, that in the following one too many ships go to Nova Zembla, and either destroy to too great an extent these mostly gregarious animals, or at least scare them away. Thus in the year 1834 some expeditions were very fortunate, after a previous cessation; in the year 1835 about 80 ships went to Nova Zembla, for which may be reckoned at least 1000 men. In the year 1836 the number of the ships diminished to one half. In the current year there were hardly more than 20 ships ; but only one, which entered the sea of Kara, made a great profit: one or two captured nearly enough to pay the cost of their fitting out, and of the rest the greater part lost far more than a half.

The most important animal for this chase is the Walrus, and after the Walrus the Dolphin (Delphinus Leucas), known under the name of the white whale, but which is here called 
Bjelucha or Bjeluga. Among the seals the sea-hare (Morskoi sajaz), Phoca leporina, Lep, $P h$. albigena, Pall., but probably not distinct from the Phoca barbata of Fabricius, gives the richest produce, both as regards its size and quantity of fat, as well as its thick skin. Phoca gronlandica bears among the Russians very different names, according to age and sex: the old full-coloured male is called Luisan or Luisun; the female, Utjälga; the not yet full-coloured animals, of a year old, they call Sjärunok and Sjärka, and the young ones, according to their different colours, Pljächanko, Chochlutschka, Bjäka. But they are not quite accurate in the application of these names to the young animals, for they also apply them to the young of a third species of seal which occurs here, and which when full-grown is called Nerpa. This seal, occurring everywhere singly on the coast, is probably Fabricius's Phoca hispida.

A fourth species of seal which belongs to these seas, though not to the coast of Nova Zembla itself, but to the Timanic coast and to the entrance of the White Sca, and even there is not frequently seen, the Tewjak, is said to cover its face with a cap : it is therefore probably the Klappmüts of the Dutch, or Phoca cristata, Erxl., Cystophora borealis, Nilsson.

Of Cetacea this sea contains in the first place a species of whale of the subdivision of fin-fish (Balanoptera), with very short whiskers, which I saw in Archangel. They rarely appear in the vicinity of Nova Zembla, and one never hears of their being stranded on this coast. Nearer to the north coast of Lapland, where they are almost yearly thrown on shore in the Motowsker bay, they are so frequent that I much wonder why the earlier attempts for the regular pursuit of this animal, difficult it is true to slay, have not been renewed and perseveringly carried on. It is worthy of remark that the Greenland whale never appears to stray into the district of Nova Zembla. For this reason we must believe that the whalefishery which the Northmen carried on, according to Ohthere's testimony*, in the ninth century, in the neighbourhood of the North Cape, was for this very fin-fish. Far more rare is the

* See King Alfred's Trauslation of Orosius, ed. Barrington, p. 211, Forster's note at the end. 
Narwal (Monodon Monoceros), and only in the neighbourhood of ice. Of Dolphins, this sea contains, besides Delphinus Leucas, Delphinus Orca (Kossatka), and a small species which the Russians call Morskaja Swinja; but I have not been able to learn whether this is Delphinus Delphis, or Delph. Phocena.

The sea mammalia in Nova Zembla would therefore be exactly the same as those known in the Spitzbergen-Greenland sea, if the Greenland whale reached as far.

On the other hand, Spitzbergen and Nova Zembla are strikingly different in their winged inhabitants. The latter country indicates by its birds the vicinity of the continent. It is richer in species, but less interesting to the naturalist; for many of these species are none other than those which yearly pass through our country, and indeed in part remain with us ; whilst another part of them go as far as Nova Zembla in order to devote themselves to the business of brooding where they may be undisturbed. Of land birds we found the Snowy Owl (Stryx Nyctea), which indeed passes the winter there; the Snow Bunting (Plectrophanes nivalis), Strepsilas collaris, Tringa maritima, and a Falcon, which was not very rare in Kostin-Schar, but which could not be shot and more closely examined. Earlier accounts also make mention of an Eagle, but the Walrus-catchers whom I questioned said they knew nothing of it. Perhaps however it is the same as the Falcon.

Among the web-footed birds which pass the season here the Saatgans are so common, at least in the southern island, that the collecting their fallen wing-feathers is an object of profit; the Ice-duck (Anas glacialis) is frequent, and the Singing Swan (Cygnus musicus) not rare.

According to the assertions of the Walrus-catchers, only one species of goose comes to NovaZembla, and we in fact got sight of no other than the Saatgans and the Brent Bernicle (Anser torquatus), which latter however does not pass for a goose among the Russians. The Eider duck or Eider goose is also not rare. The web-footed herbivorous birds however collect in much greater numbers upon the island of Kolgujew, which is described as covered with swans and geese, than in Nova Zcmbla, where the vegetation is too scanty. On this ac- 
count expeditions are sometimes sent hither to kill and salt these birds. A merchant of Archangel told me that once 15,000 geese were killed here in two hunts.

To the web-footed birds of Nova Zembla belong moreover Uria Troile (in unspeakable numbers), Uria Grylle, Colymbus septentrionalis, Sterna Hirundo, Larus glaucus, Larus canus, Larus tridactylus, Lestris catarractes, a Procellaria, which we however could not procure. Somateria spectabilis and Larus eburneus are stated to occur only on the northern coast. There also, according to the descriptions we heard, is probably found Mormon Fratercula and Mergulus Alle. It appeared very singular to me that no one had seen, south of KostinSchar, a bird of the family of Alcadce, as Alca Pica does not belong to the most northern birds, and even Mormon Fratercula occurs on the Norwegian coast.

There is no trace of the whole class of Amphibia in Nova Zembla. The Batrachia and Sauria evidently cannot exist for want of insects. Of fish, the extreme north, even where very rich in individuals, contains generally but very few species, and partly for this reason, because the fresh water does not possess its peculiar forms so numerous in warmer regions, but only the fish that ascend from the sea at certain periods. Thus Scoresby says of Spitzbergen and of the neighbouring sea, that it has but four kinds of fish. My catalogue of the fish of Nova Zembla contains ten, all of which, with the exception of the Omul (Salmo Omal, Pall.), which is said to occur on the east coast, we have ourselves seen. Among these the most important is the Alpine trout (Golez-Salmo alpinus, Fabr.), which ascends in autumn into the mountain lakes, and in many years is caught in immense quantities and exported to distant countries. All the other fish are inconsiderable or of no value for commerce, and even in the ceonomy of nature only Gadus Saida, Sep., and Cyclopterus Liparis are of any importance. 